\title{
Herpetological postage stamps issued from the Philippines
}

\author{
Indraneil Das ${ }^{1 *}$ and Genevieve V.A. Gee ${ }^{2}$
}

\begin{abstract}
In this essay, we commemorate the zoological and herpetological contributions of Angel Chua Alcala, with a review of stamps and pictorial cancellations on herpetological themes from the Philippines. Between 1982 and 2017 , a total of 79 such stamps, stamp sheetlets and undenominated tabs, depicting amphibians and reptiles have been officially issued by the postal administration of the country, all but one within its commemorative stamp releases. Species featured are those of ecotourism importance, in addition to threatened or endemic taxa, although stylized as well as non-local species too have featured on stamps produced by the country.
\end{abstract}

Keywords: Philippines, philately, stamps, postmarks, amphibians, reptiles

\section{Introduction}

The archipelagic nation of the Philippines has, over the years, issued more than its fair share of stamps on herpetological themes. Understandably, a majority of these depict marine turtles, much associated both with the country's culture and heritage and linked to ecotourism and its beaches and marine life. Herpetological motifs that have appeared include snakes, linked to the annual celebration of the Chinese Lunar New Year (the snake taking the sixth spot once in twelve years).

This essay, honoring one of Philippines' distinguished environmental heroes, Dr. Angel Chua Alcala, presents an inventory of postage stamps issued by the Philippines Post. Herpetologists have acknowledged Dr Alcala's significant work on the country's herpetofauna by naming a genus of amphibian, Alcalus, in his honor (Brown et al., 2015).

Depiction of amphibians and reptiles on stamps of the world is widespread and has been discussed in the philatelic literature (e.g., Riemer, 1993; Das, 1994, 2014; Watermolen, 1995), and specialist catalogs exist on the topic, such as those of Eichler (2017) for amphibians and Bearse et al. (1977) and

${ }^{1}$ Institute of Biodiversity and Environmental Conservation, Universiti
Malaysia Sarawak, 94300 Kota Samarahan, Sarawak, Malaysia
${ }^{2} 1 \mathrm{E} 8$ Village Grove Condominium, Lorong F, Jalan Stutong, BDC
93350 Kuching, Sarawak, Malaysia
*Corresponding email: idas@unimas.my
Date Submitted: 24 June 2020
Date Accepted: 14 December 2020

(C) Association of Systematic Biologists of the Philippines
Domfil (1992) for the herpetofauna as a whole. Published literature in herpetological philately includes regional inventories: Amr (2013) for the Middle East, and Das (2014) for Malaysia; and the use of the theme for raising conservation awareness, chiefly, marine turtles (Balazs et al., 1990; Gomez and Balazs 1983), drawing attention to other topics, such as cultural significance of herpetofaunas (Rings 2005), or understanding local perceptions of a nation's biodiversity through its philatelic releases (Nemésio et al., 2013).

All official issues from the Philippines, featuring amphibians and reptiles, were enumerated (Table 1). The cut-off date was 22 June 2020. We include here stamps that feature herpetological motifs, symbols or represent stylized species that sometimes are unrecognizable to species. Names of series follow Stanley Gibbons catalogues. Abbreviations of catalogue prefix, SG represent the Stanley Gibbons Catalog numbers (from the SG catalogues). Text figures are not reproduced to scale

\section{Results}

Philatelic issues from the Philippines started in the year 1854, during Spanish dominion under Queen Isabella II, and with "Filipinas" since 1872 from the reign of King Amadeus I, via the use of overprinted United States stamps in 1899, to the first stamps under its current name in 1946, upon the country's independence on 4 July. A postal history of the Philippines is in Encarnacion (1985). At the time of this review (22 June 2020), as many as 79 postage stamps (including stamp sheetlets and undenominated tabs) on a herpetological theme have been issued by the country (Table 1). Face values are indicated in Philippine Pesos (PHP), except for the first herpetological issue, a low-value of 40 centavos. 
Table 1. Herpetological stamps issued by the Philippines. Codes on the importance of the herpetological image include (a) primary, when the image is central to the theme, such as of direct relevance to the title of the series; (b) secondary, when the image is indirectly related to the issue; (c) herpetological motifs, symbols or stylized images unrecognizable to species. Other abbreviations include: SG, Stanley Gibbons catalog number; p, Philippine Peso.

\begin{tabular}{|c|c|c|c|c|c|c|}
\hline SI & SG & Series Name & Face value & Code & Date of issue & Species depicted \\
\hline 1 & 1707 & $\begin{array}{l}10^{\text {th }} \text { Anniversary of United } \\
\text { Nations Environmental } \\
\text { Programme }\end{array}$ & $\mathrm{p} 0.40$ & $\mathrm{~b}$ & $\begin{array}{l}5 \text { October } \\
1982\end{array}$ & Chelonia mydas \\
\hline 2 & $\begin{array}{l}2091 \\
\text { perforate }\end{array}$ & $\begin{array}{l}\text { Olympic Games, Seoul } \\
\left(1^{\text {st }} \text { Issue }\right)\end{array}$ & $\mathrm{p} 1$ & $\mathrm{~b}$ & 11 July 1988 & Chelonia mydas \\
\hline 3 & $\begin{array}{l}2091 \\
\text { imperforate }\end{array}$ & $\begin{array}{l}\text { Olympic Games, Seoul } \\
\left(1^{\text {st }} \text { Issue }\right)\end{array}$ & $\mathrm{p} 1$ & $\mathrm{~b}$ & 11 July 1988 & Chelonia mydas \\
\hline 4 & 2762 & $\begin{array}{l}\text { ASEAN Environment } \\
\text { Year } 1995\end{array}$ & $\mathrm{p} 2$ & $\mathrm{a}$ & $\begin{array}{l}10 \text { August } \\
1995\end{array}$ & Indeterminate sea turtle \\
\hline 5 & MS2764 & $\begin{array}{l}\text { ASEAN Environment } \\
\text { Year } 1995\end{array}$ & $\mathrm{p} 2$ & $\mathrm{a}$ & $\begin{array}{l}10 \text { August } \\
1995\end{array}$ & Indeterminate sea turtle \\
\hline 6 & 3021 & $\begin{array}{l}\text { International Year of the } \\
\text { Reef }\end{array}$ & $\mathrm{p} 16$ & $\mathrm{a}$ & $\begin{array}{l}24 \text { October } \\
1997\end{array}$ & Indeterminate sea turtle \\
\hline 7 & MS3022 & $\begin{array}{l}\text { International Year of the } \\
\text { Reef }\end{array}$ & $\mathrm{p} 16$ & $\mathrm{a}$ & $\begin{array}{l}24 \text { October } \\
1997\end{array}$ & Indeterminate sea turtle \\
\hline 8 & 3166 & $\begin{array}{l}\text { International Year of the } \\
\text { Ocean }\end{array}$ & $\mathrm{p} 15$ & $\mathrm{a}$ & $\begin{array}{l}24 \text { October } \\
1998\end{array}$ & Chelonia mydas \\
\hline 9 & MS3167 & $\begin{array}{l}\text { International Year of the } \\
\text { Ocean }\end{array}$ & p15 & $\mathrm{a}$ & $\begin{array}{l}24 \text { October } \\
1998 \\
\end{array}$ & Chelonia mydas \\
\hline 10 & 3234 & Frogs & $\mathrm{p} 5$ & $\mathrm{a}$ & 5 April 1999 & Rhacophorus pardalis \\
\hline 11 & 3235 & Frogs & $\mathrm{p} 5$ & $\mathrm{a}$ & 5 April 1999 & Platymantis dorsalis \\
\hline 12 & 3236 & Frogs & $\mathrm{p} 5$ & $\mathrm{a}$ & 5 April 1999 & Limnonectes woodworthi \\
\hline 13 & 3237 & Frogs & $\mathrm{p} 5$ & $\mathrm{a}$ & 5 April 1999 & Limnonectes magnus \\
\hline 14 & MS3238a & Frogs & $\mathrm{p} 5$ & $\mathrm{a}$ & 5 April 1999 & Nyctixalus spinosus \\
\hline 15 & MS3238b & Frogs & $\mathrm{p} 5$ & $\mathrm{a}$ & 5 April 1999 & Kaloula conjuncta \\
\hline 16 & MS3238c & Frogs & $\mathrm{p} 5$ & $\mathrm{a}$ & 5 April 1999 & Pulchrana granocula \\
\hline 17 & 3242 & Marine Life & $\mathrm{p} 5$ & $\mathrm{a}$ & 11 May 1999 & Laticauda colubrina \\
\hline 18 & 3391 & $\begin{array}{l}\text { New Year. Year of the } \\
\text { Snake }\end{array}$ & $\mathrm{p} 5$ & $\mathrm{a}$ & $\begin{array}{l}20 \text { December } \\
2000\end{array}$ & Pantherophis guttatus \\
\hline 19 & 3392 & $\begin{array}{l}\text { New Year. Year of the } \\
\text { Snake }\end{array}$ & p11 & $\mathrm{a}$ & $\begin{array}{l}20 \text { December } \\
2000\end{array}$ & Pantherophis guttatus \\
\hline 20 & $\begin{array}{l}\text { MS3393a } \\
\text { perforate }\end{array}$ & 2001 Year of the Snake & $\mathrm{p} 5$ & $\mathrm{a}$ & $\begin{array}{l}20 \text { December } \\
2000\end{array}$ & Pantherophis guttatus \\
\hline 21 & $\begin{array}{l}\text { MS3393b } \\
\text { perforate }\end{array}$ & 2001 Year of the Snake & $\mathrm{p} 11$ & $\mathrm{a}$ & $\begin{array}{l}20 \text { December } \\
2000\end{array}$ & Pantherophis guttatus \\
\hline 22 & $\begin{array}{l}\text { MS3393a } \\
\text { imperforate }\end{array}$ & 2001 Year of the Snake & $\mathrm{p} 5$ & $\mathrm{a}$ & $\begin{array}{l}20 \text { December } \\
2000\end{array}$ & Pantherophis guttatus \\
\hline 23 & $\begin{array}{l}\text { MS3393b } \\
\text { imperforate }\end{array}$ & 2001 Year of the Snake & p11 & $\mathrm{a}$ & $\begin{array}{l}20 \text { December } \\
2000\end{array}$ & Pantherophis guttatus \\
\hline 24 & 3401 & $\begin{array}{l}\text { Hong Kong 2001. Interna- } \\
\text { tional Stamp Exhibition. } \\
\text { Flora and Fauna }\end{array}$ & $\mathrm{p} 5$ & a & $\begin{array}{l}3 \text { February } \\
2001\end{array}$ & Eretmochelys imbricata \\
\hline 25 & MS3403c & $\begin{array}{l}\text { Hong Kong 2001. Interna- } \\
\text { tional Stamp Exhibition. } \\
\text { Flora and Fauna }\end{array}$ & $\mathrm{p} 11$ & $\mathrm{a}$ & $\begin{array}{l}3 \text { February } \\
2001\end{array}$ & Eretmochelys imbricata \\
\hline
\end{tabular}


Das \& Gee: Herpetological Stamps Issued from the Philippines

Cont'd. Table 1. Herpetological stamps issued by the Philippines.

\begin{tabular}{|c|c|c|c|c|c|c|}
\hline SI & SG & Series Name & Face value & Code & Date of issue & Species depicted \\
\hline 26 & MS3505 & $\begin{array}{l}\text { Fisheries and Coastal Re- } \\
\text { sources Conservation }\end{array}$ & p5 & $\mathrm{a}$ & 24 June 2002 & Indeterminate sea turtle \\
\hline 27 & 3692 & $\begin{array}{l}\text { The Twelve Animals of } \\
\text { the Lunar New Year Cycle }\end{array}$ & p6 & $\mathrm{a}$ & $\begin{array}{l}9 \quad \text { September } \\
2004\end{array}$ & Pantherophis guttatus \\
\hline 28 & 3870 & Philippine Marine Turtles & p7 & $\mathrm{a}$ & $\begin{array}{ll}31 & \text { March } \\
2006 & \end{array}$ & Lepidochelys olivacea \\
\hline 30 & 3872 & Philippine Marine Turtles & p7 & $\mathrm{a}$ & $\begin{array}{ll}31 & \text { March } \\
2006 & \\
\end{array}$ & Caretta caretta \\
\hline 31 & 3873 & Philippine Marine Turtles & p7 & $\mathrm{a}$ & $\begin{array}{ll}31 & \text { March } \\
2006 & \end{array}$ & Dermochelys coriacea \\
\hline 32 & MS3874 & Philippine Marine Turtles & $\mathrm{p} 26$ & $\mathrm{a}$ & $\begin{array}{ll}31 & \text { March } \\
2006 & \end{array}$ & Chelonia mydas \\
\hline 34 & 4458 & Philippine Crocodile & $\mathrm{p} 7$ & $\mathrm{a}$ & 16 May 2011 & Crocodylus mindorensis \\
\hline 35 & 4459 & Philippine Crocodile & p7 & $\mathrm{a}$ & 16 May 2011 & Crocodylus mindorensis \\
\hline 36 & 4460 & Philippine Crocodile & $\mathrm{p} 7$ & $\mathrm{a}$ & 16 May 2011 & Crocodylus mindorensis \\
\hline 37 & 4461 & Philippine Crocodile & $\mathrm{p} 7$ & $\mathrm{a}$ & 16 May 2011 & Crocodylus mindorensis \\
\hline 38 & 4495 & $\begin{array}{l}\text { Philippine Endemic } \\
\text { Lizards }\end{array}$ & $\mathrm{p} 7$ & $\mathrm{a}$ & $\begin{array}{ll}30 & \text { August } \\
2011 & \end{array}$ & Otosaurus cumingi \\
\hline 39 & 4496 & $\begin{array}{l}\text { Philippine Endemic } \\
\text { Lizards }\end{array}$ & p7 & $\mathrm{a}$ & $\begin{array}{ll}30 & \text { August } \\
2011 & \end{array}$ & Gekko carusadensis \\
\hline 43 & MS4499b & $\begin{array}{l}\text { Philippine Endemic } \\
\text { Lizards }\end{array}$ & p7 & $\mathrm{a}$ & $\begin{array}{ll}30 & \text { August } \\
2011 & \end{array}$ & Tropidophorus grayii \\
\hline 44 & MS4499c & $\begin{array}{l}\text { Philippine Endemic } \\
\text { Lizards }\end{array}$ & p7 & $\mathrm{a}$ & $\begin{array}{ll}30 & \text { August } \\
2011 & \\
\end{array}$ & Hydrosaurus pustulatus \\
\hline 45 & MS4499d & $\begin{array}{l}\text { Philippine Endemic } \\
\text { Lizards }\end{array}$ & p7 & $\mathrm{a}$ & $\begin{array}{l}30 \quad \text { August } \\
2011 \quad\end{array}$ & Brachymeles elerae \\
\hline 46 & 4538 & Endemic Frogs & p7 & $\mathrm{a}$ & $\begin{array}{l}15 \text { December } \\
2011\end{array}$ & Nyctixalus spinosus \\
\hline 47 & 4539 & Endemic Frogs & p7 & $\mathrm{a}$ & $\begin{array}{l}15 \text { December } \\
2011\end{array}$ & Platymantis pygmaeus \\
\hline 48 & 4540 & Endemic Frogs & $\mathrm{p} 7$ & $\mathrm{a}$ & $\begin{array}{l}15 \text { December } \\
2011\end{array}$ & Barbourula busuangensis \\
\hline 49 & 4541 & Endemic Frogs & $\mathrm{p} 7$ & $\mathrm{a}$ & $\begin{array}{l}15 \text { December } \\
2011\end{array}$ & Platymantis biak \\
\hline 50 & MS4542a & Endemic Frogs & $\mathrm{p} 7$ & $\mathrm{a}$ & $\begin{array}{l}15 \text { December } \\
2011\end{array}$ & Rhacophorus pardalis \\
\hline
\end{tabular}


Das \& Gee: Herpetological Stamps Issued from the Philippines

Cont'd. Table 1. Herpetological stamps issued by the Philippines.

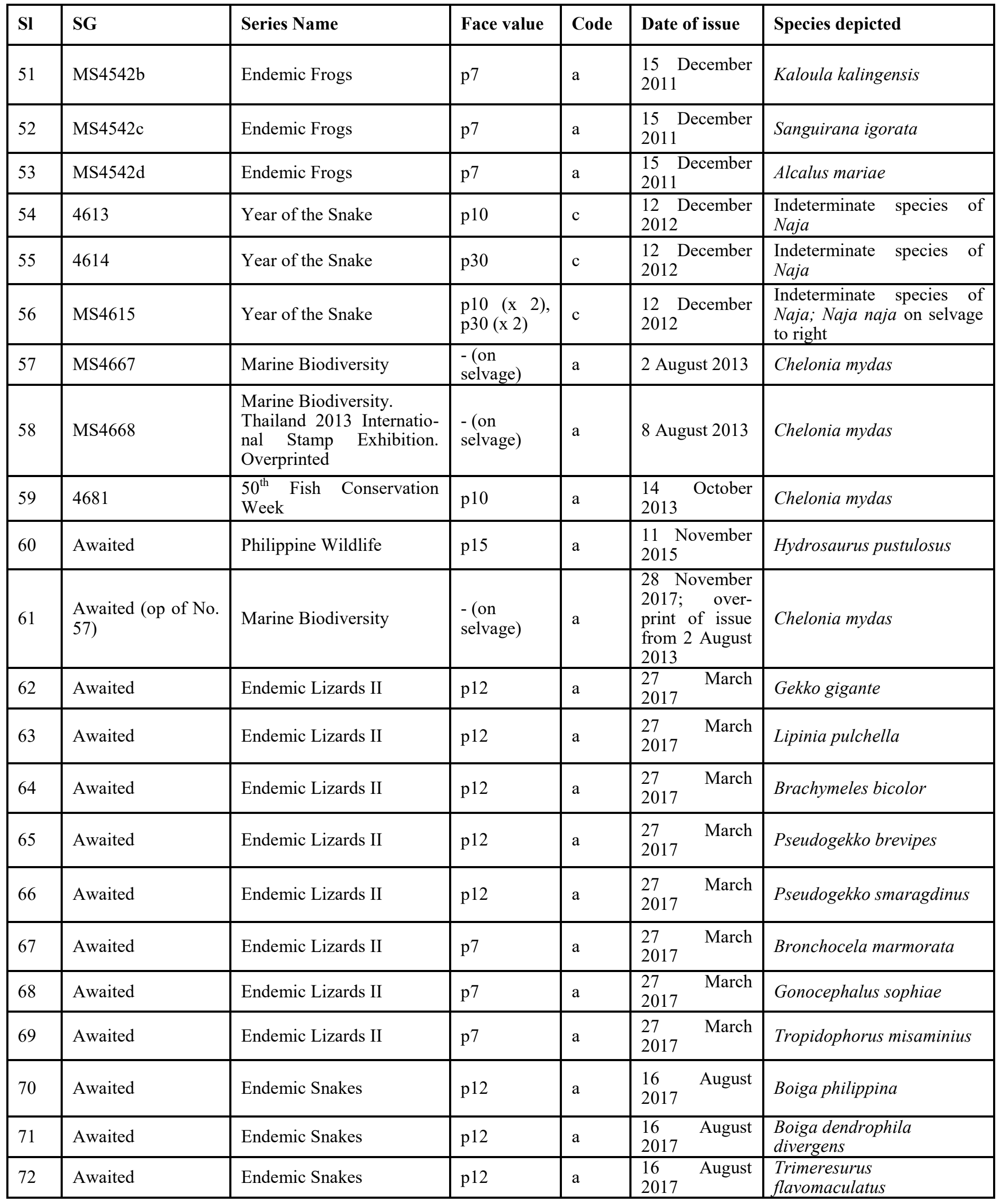


Das \& Gee: Herpetological Stamps Issued from the Philippines

Cont'd. Table 1. Herpetological stamps issued by the Philippines.

\begin{tabular}{|c|c|c|c|c|c|c|}
\hline SI & SG & Series Name & Face value & Code & Date of issue & Species depicted \\
\hline 73 & Awaited & Endemic Snakes & $\mathrm{p} 12$ & $\mathrm{a}$ & $\begin{array}{l}16 \quad \text { August } \\
2017\end{array}$ & Malayotyphlops ruficaudus \\
\hline 74 & Awaited & Endemic Snakes & $\mathrm{p} 25$ & $\mathrm{a}$ & $\begin{array}{ll}16 & \text { August } \\
2017 & \end{array}$ & $\begin{array}{l}\text { Chrysopelea paradisi } \\
\text { variabilis }\end{array}$ \\
\hline 75 & Awaited & Endemic Snakes & $\mathrm{p} 25$ & $\mathrm{a}$ & $\begin{array}{ll}16 & \text { August } \\
2017 & \\
\end{array}$ & Lycodon ferroni \\
\hline 77 & Awaited & Endemic Snakes & $\mathrm{p} 25$ & $\mathrm{a}$ & $\begin{array}{ll}16 & \text { August } \\
2017 & \end{array}$ & Dryophiops philippina \\
\hline 78 & - & Endemic Snakes & $\begin{array}{l}\text { - (on } \\
\text { selvage) }\end{array}$ & $\mathrm{a}$ & $\begin{array}{l}16 \quad \text { August } \\
2017\end{array}$ & $\begin{array}{l}\text { Trimeresurus } \\
\text { flavomaculatus }\end{array}$ \\
\hline
\end{tabular}

The country's first such stamp (Fig. 1), under its official postal administration appeared on 5 October 1982, under the series $10^{\text {th }}$ Anniversary of the United Nations Environmental Programme (UNEP). It depicts a Green Turtle, Chelonia mydas on a 40 centavo (= PHP 0.40) stamp. The commemorative issue was significant as UNEP, at this meeting, initiated an environmental awards programme for the recognition of prominent individuals or organizations that have made substantial contributions towards environmental protection.

The second issue was from 11 July 1988, again a Green Turtle, Chelonia mydas, along with a diver, strangely issued to commemorate the Summer Olympics ("Games of the XXIV Olympiad") of 1988 at Seoul, South Korea (Fig. 2). The design appears in perforate as well as imperforate formats, in a setenant strip of four.

The next four stamps and stamp sheetlets depict indeterminate species of marine turtles, two of which appear in releases from the ASEAN Environment Year, 10 August 1995 (Fig. 3) and the International Year of the Reef, 24 October 1997 (Fig. 4). In both cases, although given separate catalog numbers, the postal authority uses the same stamp design. The pattern continues in the release commemorating the International Year of the Ocean, 24 October 1998 (Fig. 5), with the stamp and sheetlet showing a marine scene and depicting a Green Turtle, Chelonia mydas.

Philippines Post started looking landwards with a release on frogs on 5 April 1999 (Fig. 6). The issue is a significant one, being the first to cover the archipelago's diverse amphibian fauna, commemorated via a four value set of stamps (each of PHP 5), showing Rhacophorus pardalis, Platymantis dorsalis, Limnonectes woodworthi, and Limnonectes magnus (Fig. 6) Additionally, there was a sheetlet of three value stamps (also of PHP 5 value) that show Nyctixalus spinosus, Kaloula conjuncta, and Pulchrana granocula (Fig. 6).
The following month, on 11 May 1999, the agency issued a set of four stamps (PHP 5 each), issued in se-tenant, on these islands' marine life, one showing Laticauda colubrina (Fig. 7).

The Chinese New Year is the most significant of festive occasions for the Chinese diaspora worldwide, and currently, 77 countries and postal authorities issue commemoratives to mark the event. Of late, the Chinese Shengxiao (Zodiac) Philatelic Society has been organizing a philatelic contest to recognise the best Chinese zodiac stamps. Therefore, with a twinge of disappointment, herpetologists saw the North American Corn Snake, Pantherophis guttatus on stamps and sheetlets from the country, issued on 20 December 2000. The two designs (of PHP 5 and 11), showing a regular color morph and an albinistic one, appear both as separate stamps as well as on miniature sheets, in perforate and imperforate formats (Fig. 8). However, the sheetlets themselves look festive enough, with additional undenominated tabs, showing stylized snakes as well as illustrated selvage on top.

The next few releases revert back to the favorite thememarine life. On 3 February 2001, at the Hong Kong International Stamp Exhibition, held 1-5 February 2001 in Hall 1 of the Hong Kong Convention and Exhibition Centre, the Philippines issued a stamp and a sheetlet (Fig. 9) showing a Hawksbill Sea Turtle, Eretmochelys imbricata (PHP 5 and 11, respectively). Marine theme continued with a se-tenant block of four on the theme "Fisheries and Coastal Resources Conservation", issued on 24 June 2002 (Fig. 10), that include a stamp showing an indeterminate sea turtle (PHP 5).

The American Corn Snake, Pantherophis guttatus made a perhaps unwelcome return in a release from 9 September 2004, from a sheet entitled "The Twelve Animals of the Lunar New Year Cycle". Issued on 9 September 2004, each of the 12 stamps (of PHP 6 face value each) features an animal from the Chinese zodiac (Fig. 11). 
Table 2. Herpetological cancellations from the Philippines.

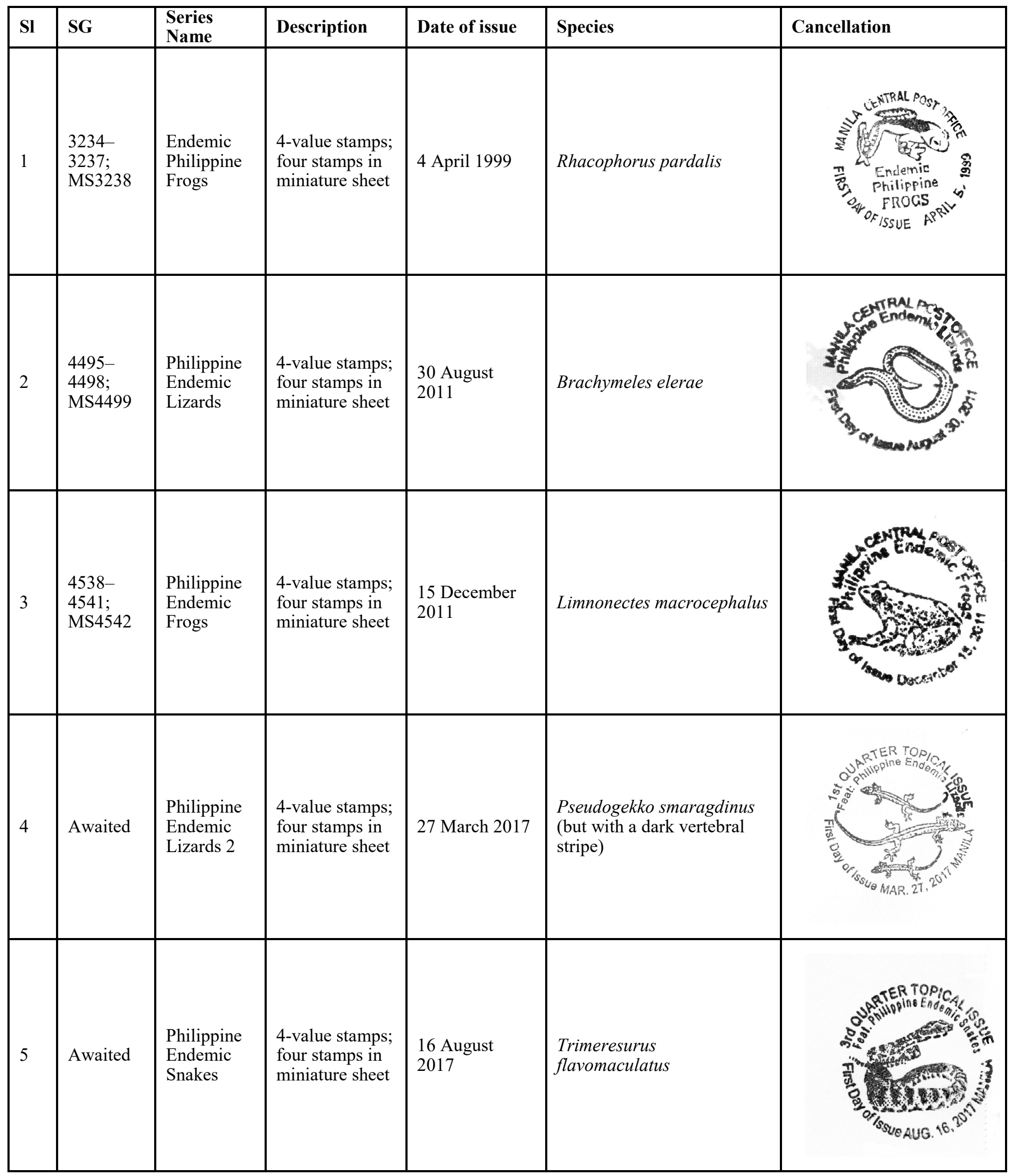


Marine turtles, representing all the known local species, appear in the next release, a well-designed issue from 31 March 2006 (Fig. 12), the four stamps of PHP 7 value each, the sheetlet indicated as of PHP 26 value. The stamp sets depict Lepidochelys olivacea, Eretmochelys imbricata, Caretta caretta, and Dermochelys coriacea; the sheetlet shows a Chelonia mydas.

Between 29 March 2010 and 20 January 2011, the Philippines released a series of 37 stamps under a new definitive series on marine biodiversity. One of these (a PHP 5 stamp), issued 18 November 2010, features a Green Turtle, Chelonia mydas (Fig. 13).

Two species of crocodilians occur in the archipelago, and while the Saltwater Crocodile, Crocodylus porosus has appeared in dozens of stamps worldwide, the endemic Philippine Crocodile, Crocodylus mindorensis, which is listed as 'Critically Endangered' in the IUCN Red List (IUCN 2020), appears to have been thus far neglected. Matters were set right on 16 May 2011, when Philippines Post released a set of four stamps (PHP 7 each), depicting the species (Fig. 14).

One of the most attractive herpetological stamps brought out by the country was in the series from 30 August 2011, entitled "Philippines Endemic Lizards" (Fig. 15). The species depicted are endemics to the islands and many obscure or then recently described. The authorities worked with the Philippine National Museum staff herpetologist, Arvin Cantor Diesmos, to get accurate portrayal of these species. The four value stamps appear in sets of four on each sheet, and depict the following species in each stamp (of PHP 7 face value): Otosaurus cumingi, Gekko carusadensis, Cyrtodactylus mamanwa, and Parvoscincus leucospilos (under its older name, Sphenomorphus leucospilos). The stamp sheetlet is composed of four stamps (PHP 7 each) and depict Gonocephalus sophiae, Tropidophorus grayii, Hydrosaurus pustulatus, and Brachymeles elerae. The top left quarter of the sheetlet has an Otosaurus cumingi (under an earlier name, Sphenomorphus cumingi), printed across two undenominated tabs.

The next release is the second series of an earlier theme, on the endemic frogs of the Philippines (Fig. 16). The date of issue is 15 December 2011, and the contents include four stamps (PHP 7 each) and a sheetlet of four stamps (also of the same denomination). Species depicted on the stamps are Nyctixalus spinosus, Platymantis pygmaeus, Barbourula busuangensis, and Platymantis biak. The sheetlet shows Rhacophorus pardalis, Kaloula kalingensis, Sanguirana igorata, and Alcalus mariae (under its earlier name, Ingerana mariae), besides an undenominated tab showing Limnonectes macrocephalus.
It is the year 2013, which brings back the 'Year of the Snake'. This time around, the Corn Snake is replaced by an indeterminate species of cobra, Naja, on a release from 12 December 2012 (Fig. 17). The two snake stamps are of PHP 10 and 30, while the sheetlet has the same design and denomination, reproduced in sets of two. Additionally, the broad selvage on the right bears an image of the Indian Cobra, Naja naja.

A large sheet was issued on 2 August 2013 on the theme "Marine Biodiversity" (Fig. 18). No herpetological species feature on the eight triangular stamps (PHP 10 each) but the top left (the 'northwestern corner' of philatelists) of the sheetlet has a swimming Green Turtle, Chelonia mydas. This beautiful sheet was reissued 28 November 2018, overprinted with the logo of the Thailand World Stamp Exhibition, held in Bangkok, 28 November to 3 December 2018 (Fig. 19).

The Green Turtle, Chelonia mydas, appears again in a release on 14 October 2013 (Fig. 20), entitled " $50^{\text {th }}$ Fish Conservation Week". The release commemorates the Bureau of Fisheries and Aquatic Resources, and included three se-tenant stamps in a sheetlet, each of face value PHP 10. Herpetologists will recollect that the American herpetologist - World War II spy (Borrell, 2013), Edward Harrison Taylor (1889-1978), was Chief of its precursor, the Division of Fisheries, Manila, between 1916-1920.

On 11 November 2015, the country issued a vertical sheetlet commemorating the wildlife of the Philippines via a sheetlet of PHP $15 \times 4$ (Fig. 21) that depicts four species, including the Philippines Sail-fin Lizard, Hydrosaurus pustulosus. Although based on photographs, rather than the typical imagery seen in the country's stamps, the bright green cast on the lizard does not reflect the true color known in this species.

On 27 March 2017, a series entitled "Philippines Endemic Lizards II" (Fig. 22) was released, comprising four stamps (PHP 12 each) depicting Gekko gigante, Lipinia pulchella, Brachymeles bicolor, and Pseudogekko brevipes. The accompanying sheetlet comprise four stamps (also PHP 12 each), which show Pseudogekko smaragdinus, Bronchocela marmorata, Gonocephalus sophiae, and Tropidophorus misaminius). A large image of Varanus olivaceus, perhaps the most famous of the country's herpetofauna, a frugivorous varanid, sprawls across two undenominated portions of the sheetlet.

The last series to be discussed is arguably Philippines finest, and cover the last great group not dealt with in detail (excluding a marine snake and the exotic or unrecognisable species from Chinese New Year). On 16 August 2017, the postal 


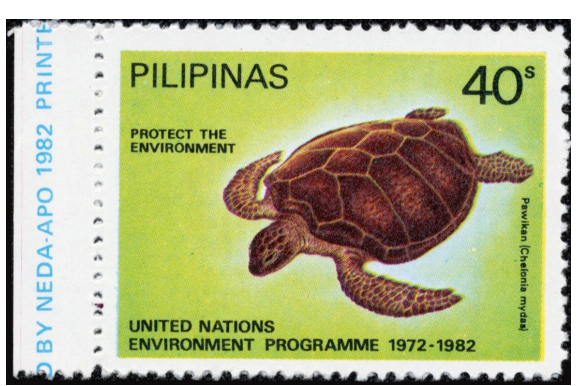

Figure 1. SG 1707, "10th Anniversary of United Nations Environmental Programme" (Chelonia mydas).
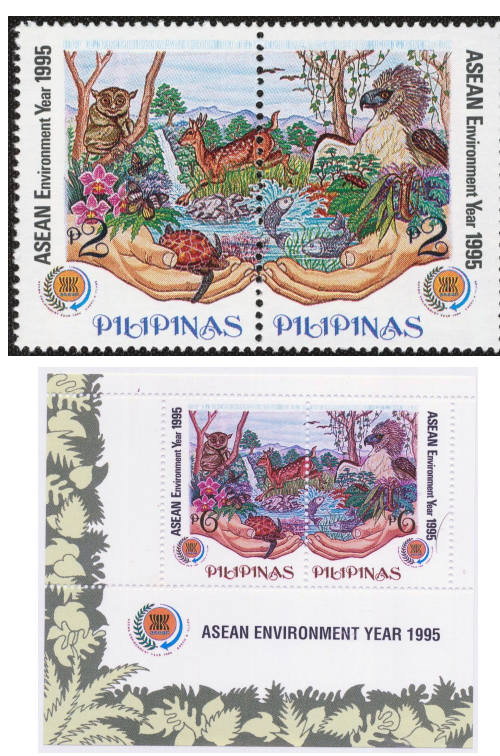

Figure 3. SG 2762 and MS2764 (stamp on top; sheetlet at bottom), "ASEAN Environment Year 1995" (Indeterminate sea turtle).

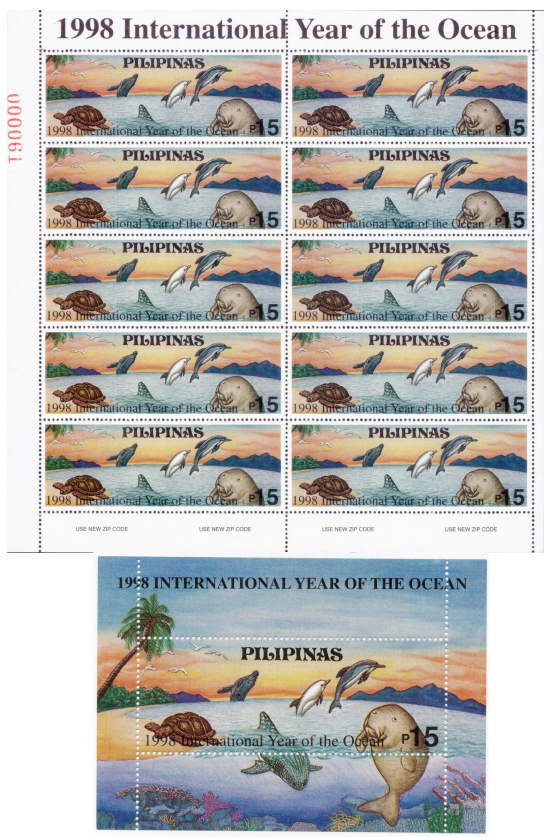

Figure 5. SG 3166 and MS3167 (stamp, with white edges, top; sheetlet, bottom), "International Year of the Ocean" (Chelonia mydas).

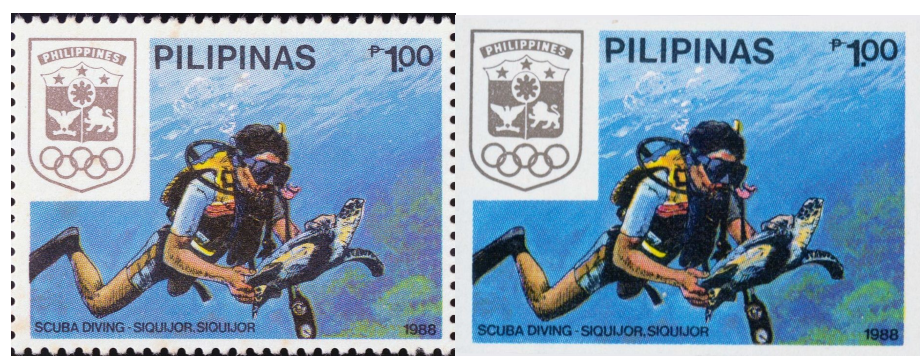

Figure 2. SG 2091 (perforate, left; imperforate, right), "Olympic Games, Seoul (1st Issue)" (Chelonia mydas).

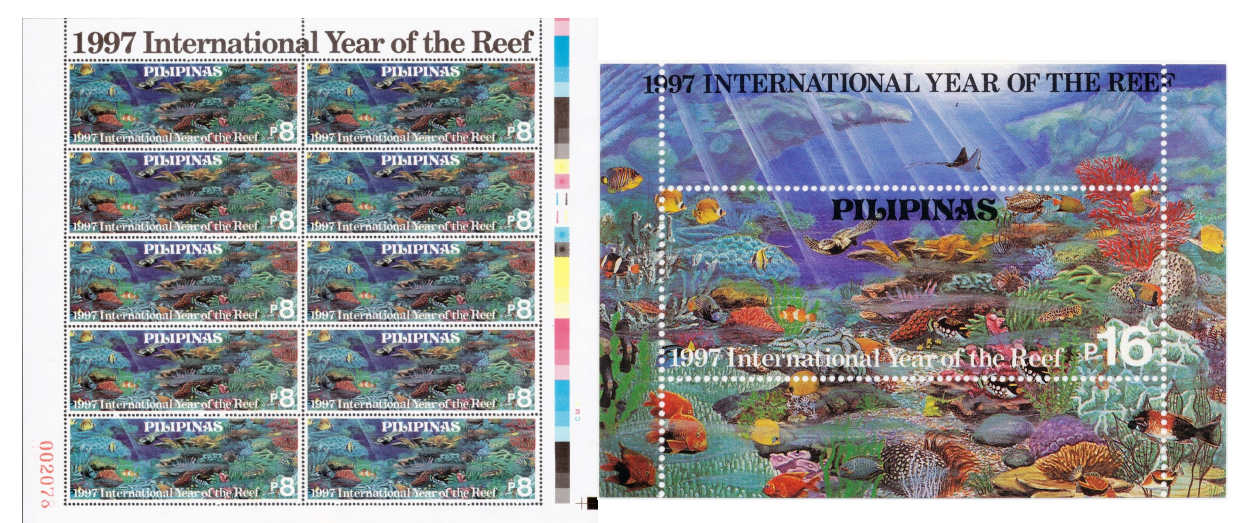

Figure 4. SG 3021 and MS3022 (stamp with white edges, left; sheetlet, right), "International Year of the Reef" (Indeterminate sea turtle).

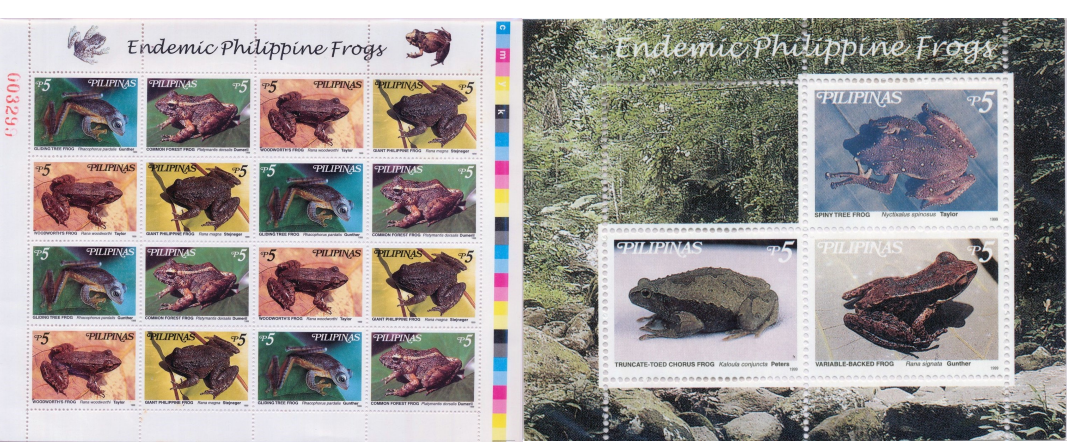

Figure 6. SG 3234-3237; MS3238a-3238c (stamps, left; sheetlet, right), "Endemic Philippine Frogs" (Rhacophorus pardalis, Platymantis dorsalis, Limnonectes woodworthi, Limnonectes magnus, Nyctixalus spinosus, Kaloula conjuncta and Pulchrana granocula).

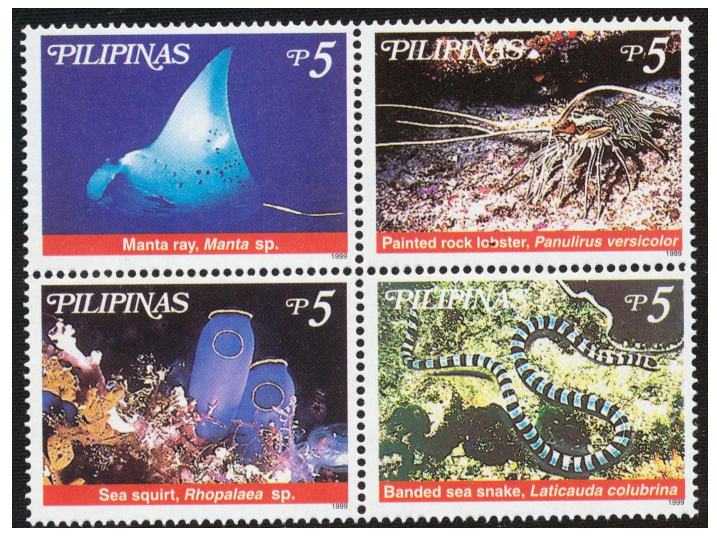

Figure 7. SG 3242, "Marine Life" (Laticauda colubrina). 


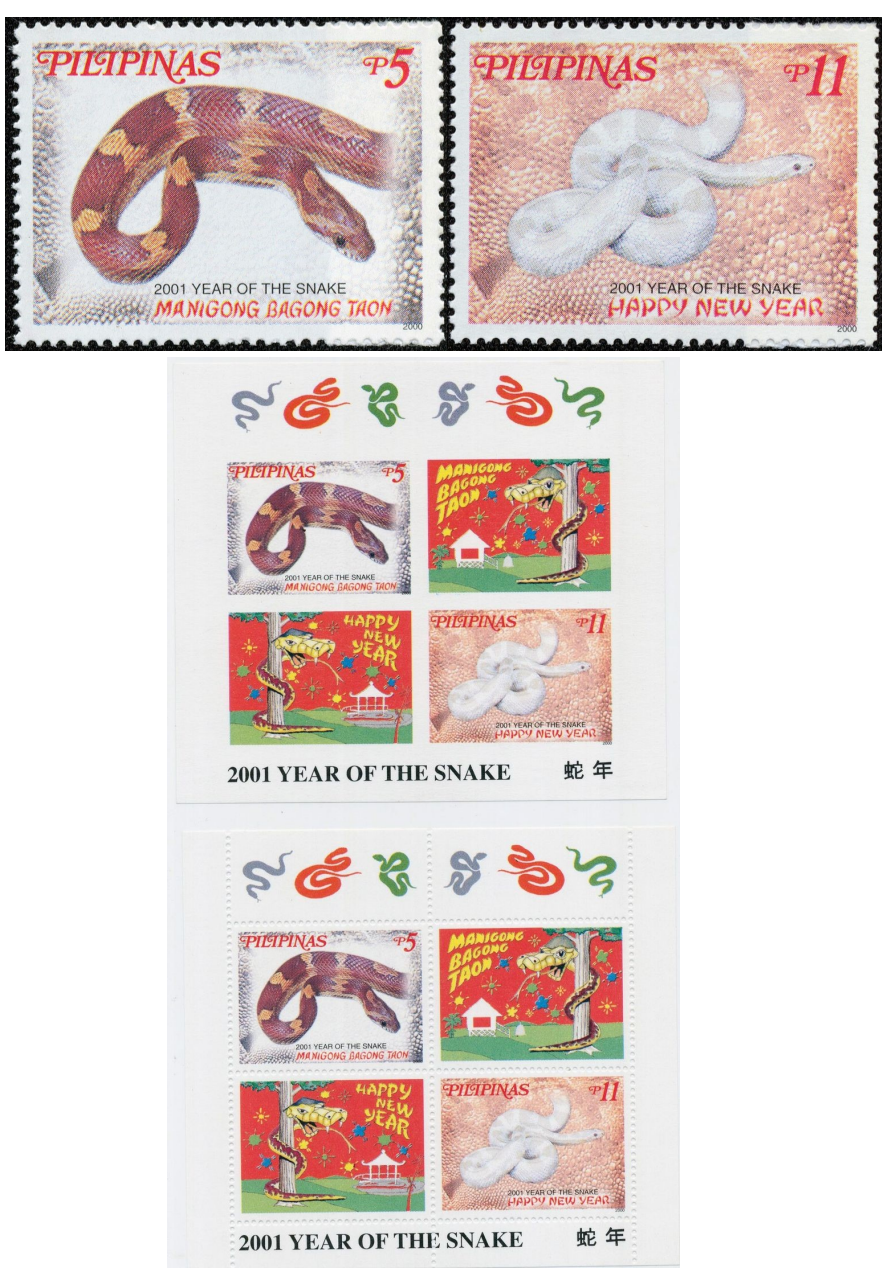

Figure 8. SG 3391-3392; MS3393a-3393b (stamps, top; sheetlets, bottom), "New Year. Year of the Snake" (Pantherophis guttatus).

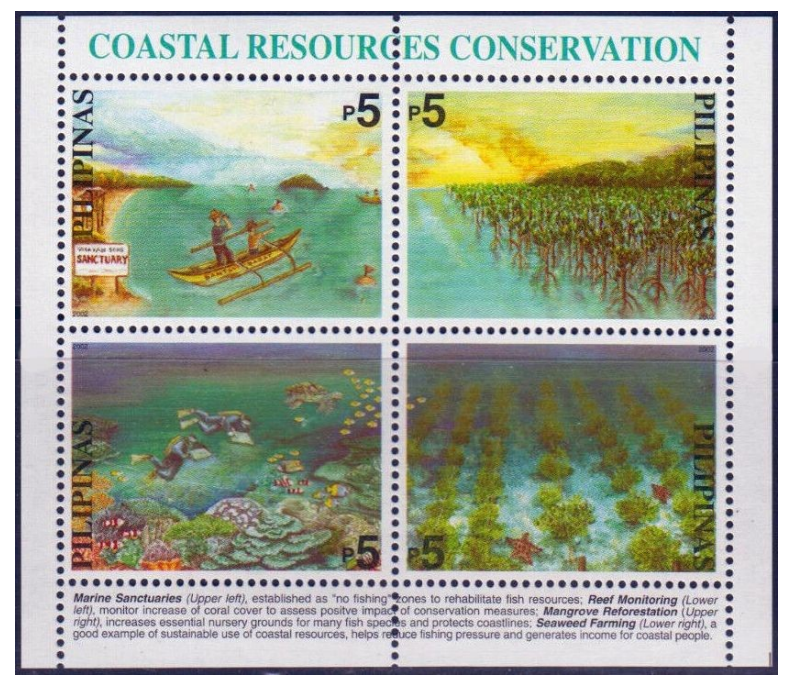

Figure 10. SG MS3505, "Fisheries and Coastal Resources Conservation" (Indeterminate sea turtle).

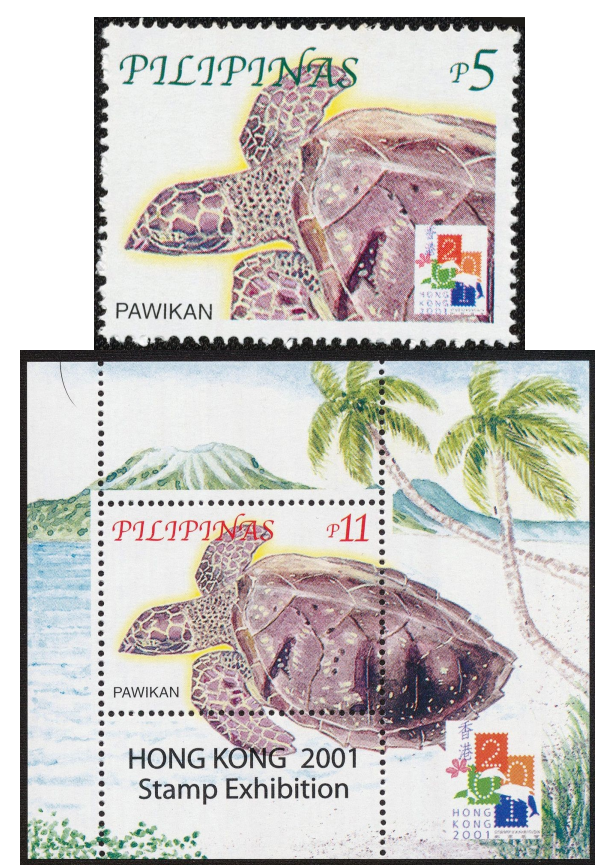

Figure 9. SG 3401; MS3403c (stamps, on top; sheetlet, bottom), "Hong Kong 2001. International Stamp Exhibition. Flora and Fauna" (Eretmochelys imbricata).
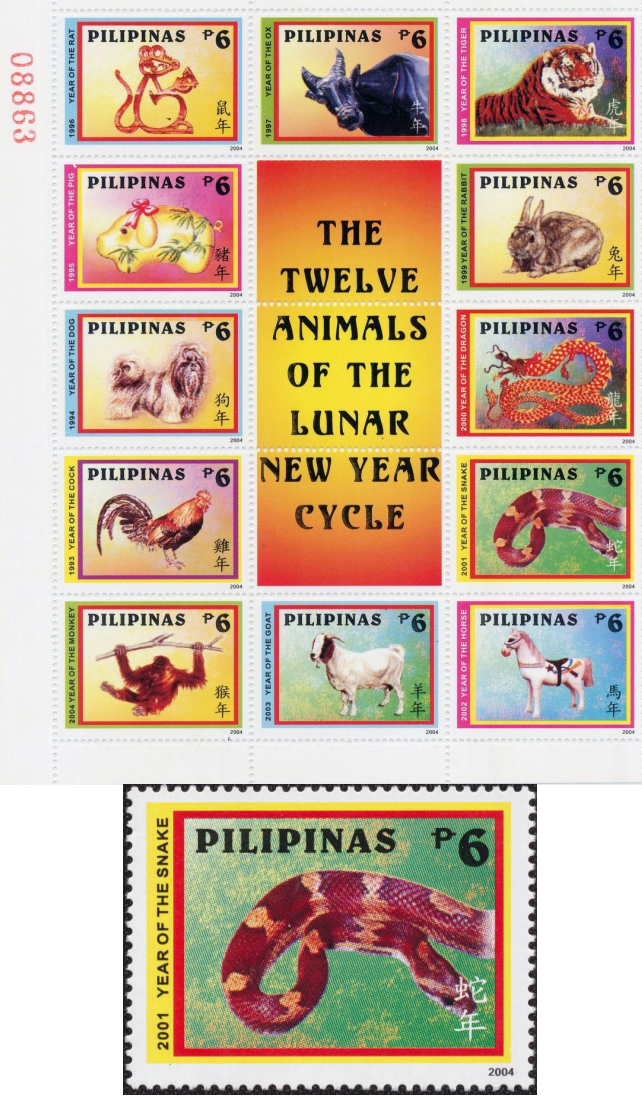

Figure 11. SG 3692 (sheetlet on top), "The Twelve Animals of the Lunar New Year Cycle" (Pantherophis guttatus reproduced at bottom). 


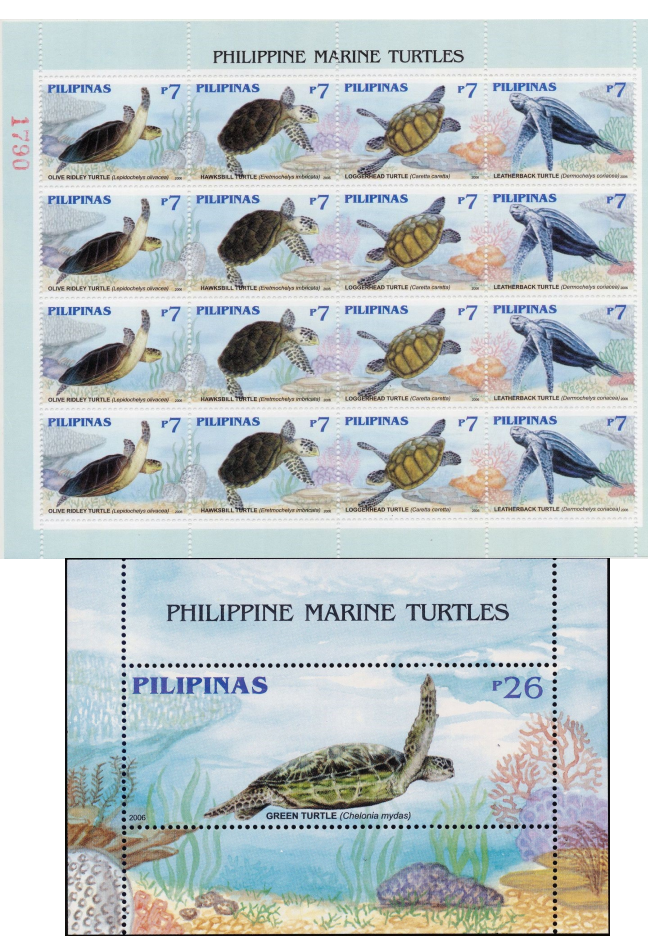

Figure 12. SG 3870-3873; MS3875 (stamps, top; sheetlet, bottom), "Philippine Marine Turtles" (Lepidochelys olivacea, Eretmochelys imbricata, Caretta caretta, Dermochelys coriacea and Chelonia mydas).

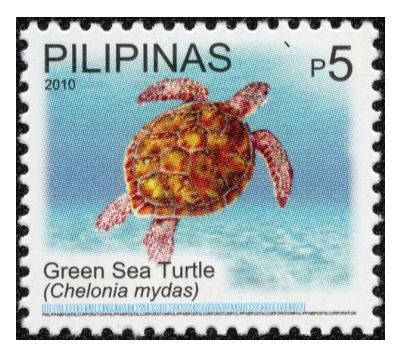

Figure 13. SG 4308, "Philippines Marine Biodiversity" (Chelonia mydas).

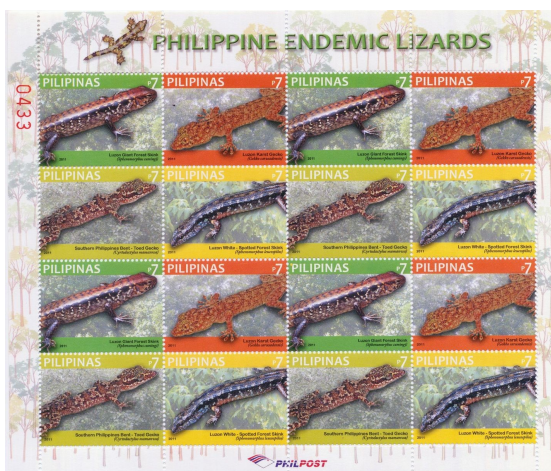

PHELIPPINE ENDEMIC LIZARDS.

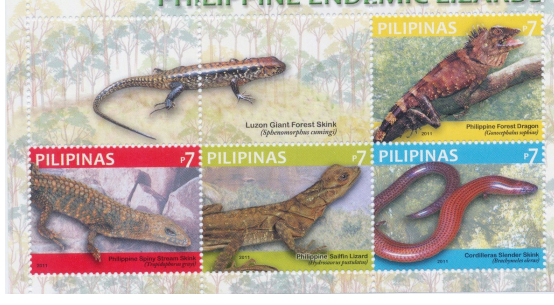

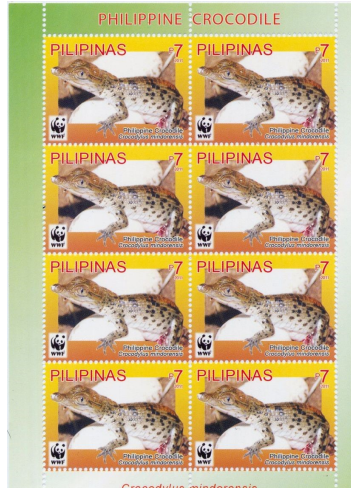
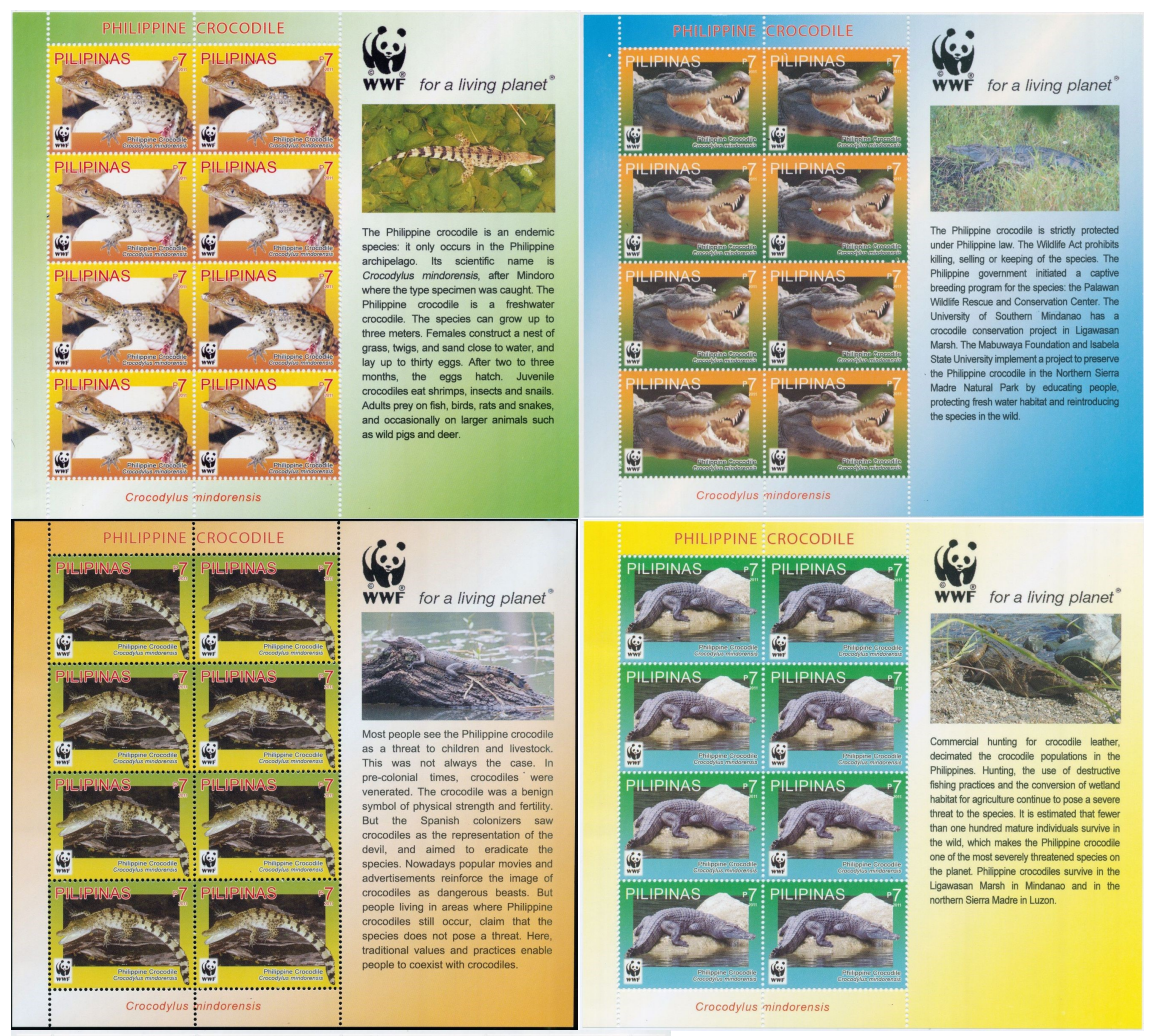

Figure 14. SG 4458-4461, "Philippine Crocodile" (Crocodylus mindorensis).
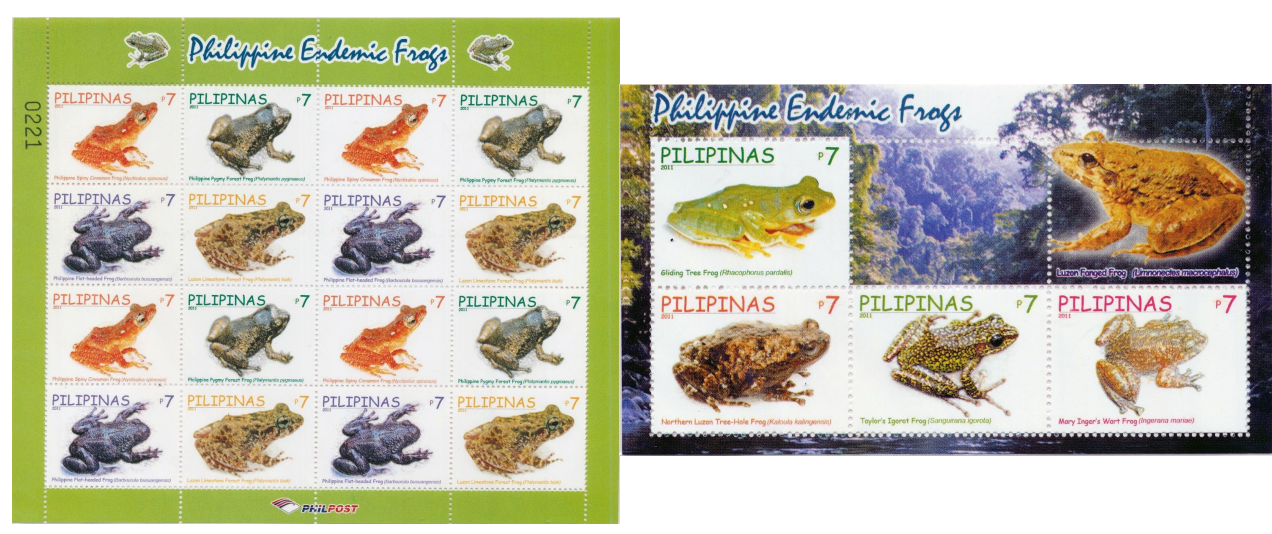

Figure 16. SG4538-4541; MS4542a-d (stamps, left; sheetlet, right), "Endemic Frogs (Nyctixalus spinosus, Platymantis pygmaeus, Barbourula busuangensis, Platymantis biak, Rhacophorus pardalis, Kaloula kalingensis, Sanguirana igorata and Alcalus mariae).

Figure 15. SG4495-4498; MS4499a-d (stamps, top; sheetlet, bottom), "Philippines Endemic Lizards" (Otosaurus cumingi, Gekko carusadensis, Cyrtodactylus mamanwa, Parvoscincus leucospilos, Gonocephalus sophiae, Tropidophorus grayii, Hydrosaurus pustulatus and Brachymeles elerae). 


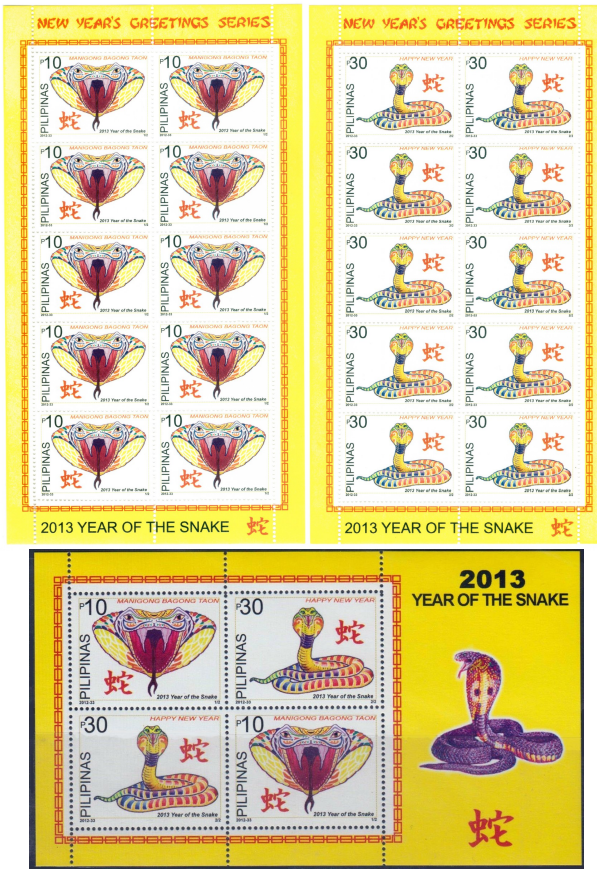

Figure 17. SG 4613-4614; MS4615 (stamps, top; sheetlet, bottom), "Year of the Snake" (Indeterminate species of Naja); Naja naja on selvage of sheetlet.

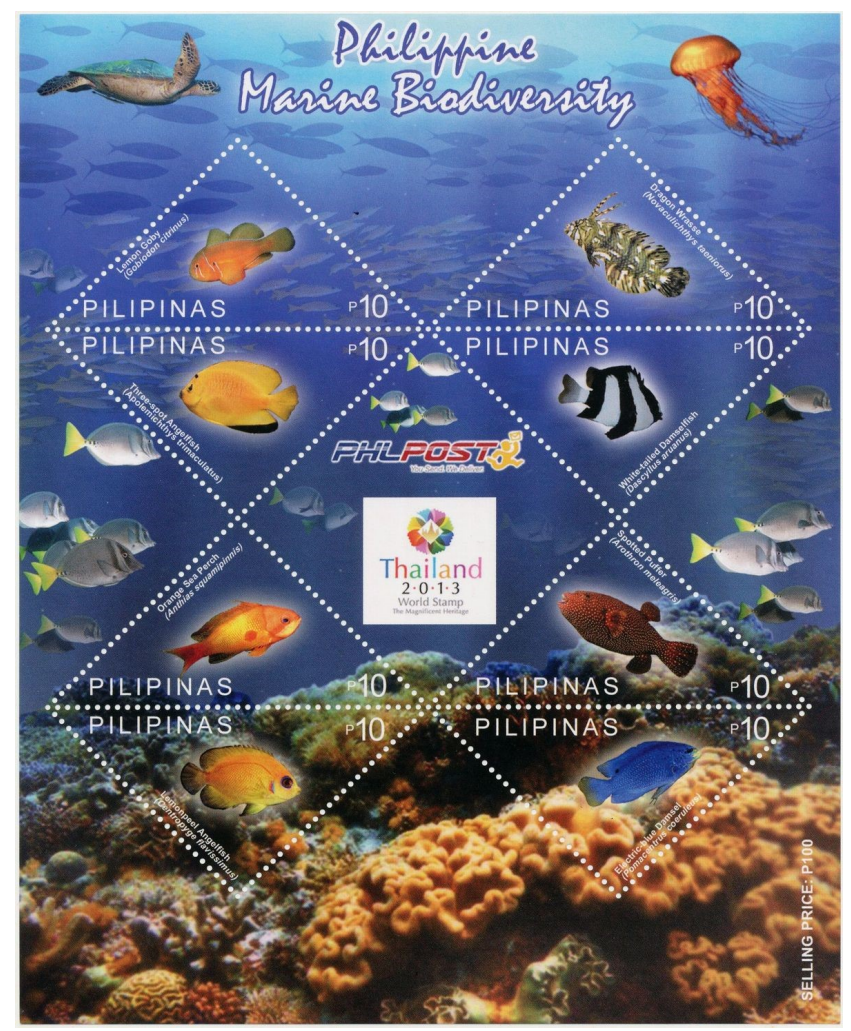

Figure 19. SG MS4668 "Marine Biodiversity” (Chelonia mydas).

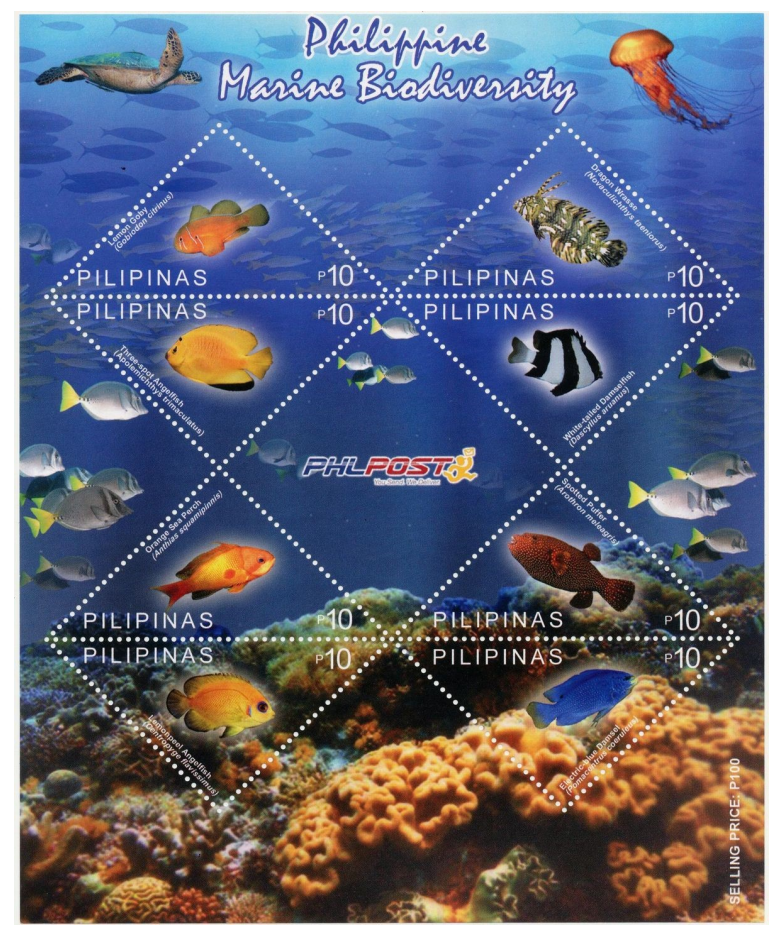

Figure 18. SG MS4667 "Marine Biodiversity" (Chelonia mydas)

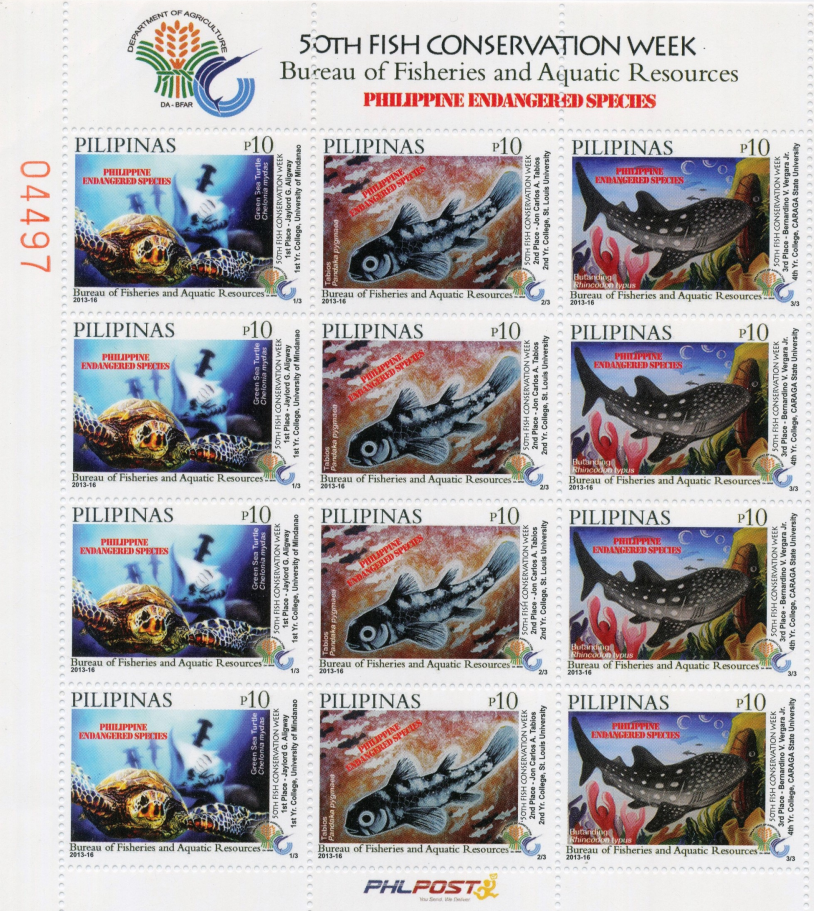

Figure 20. SG 4681, "50th Fish Conservation Week" (Chelonia mydas). 


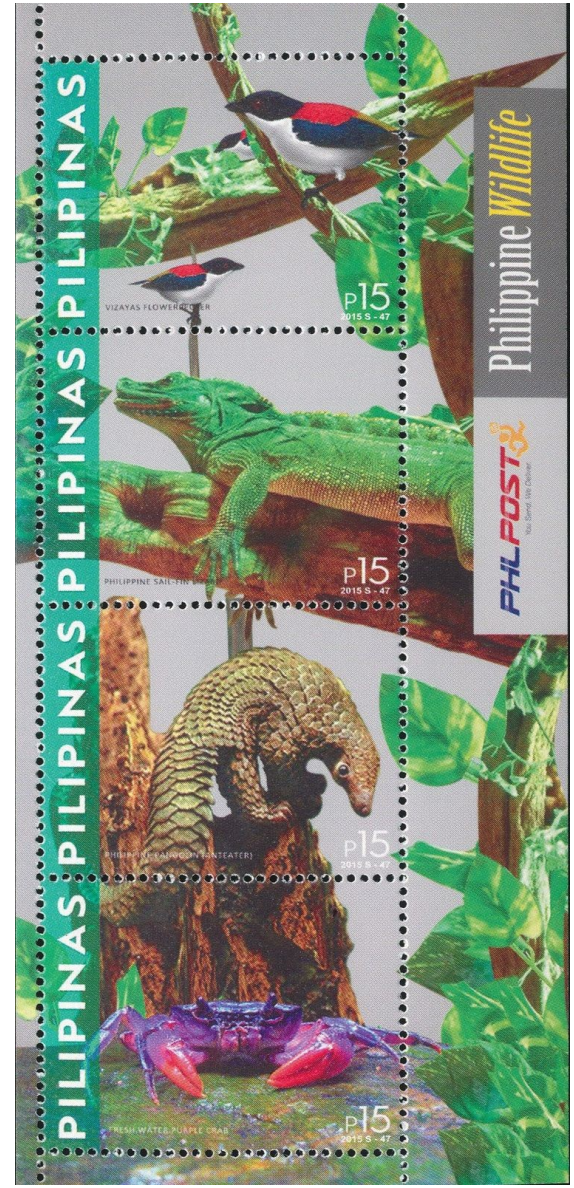

Figure 21. SG awaited, "Philippine Wildlife" (Hydrosaurus pustulosus).
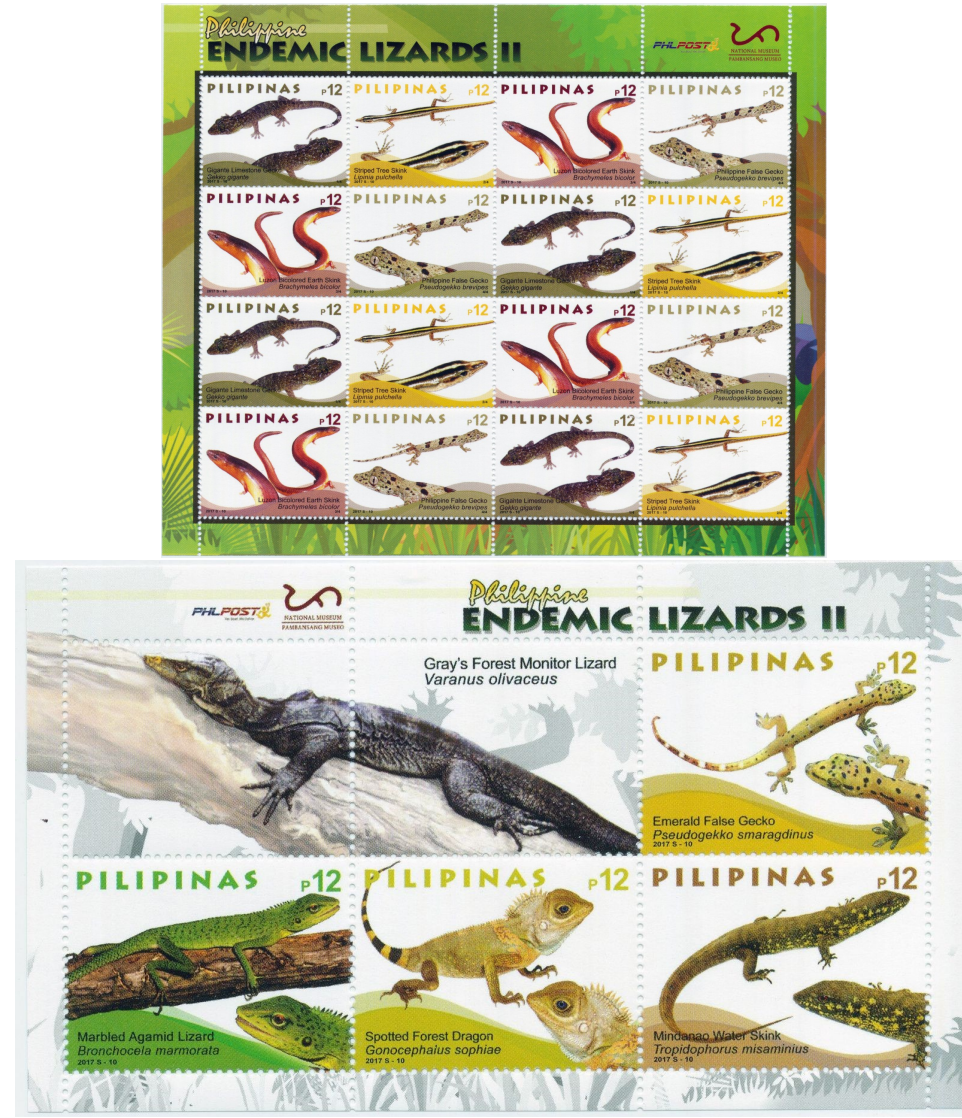

Figure 22. SG awaited (stamps, top; sheetlet, bottom), "Philippines Endemic Lizards II" (Gekko gigante, Lipinia pulchella, Brachymeles bicolor, Pseudogekko brevipes, Pseudogekko smaragdinus, Bronchocela marmorata, Gonocephalus sophiae, and Tropidophorus misaminius).
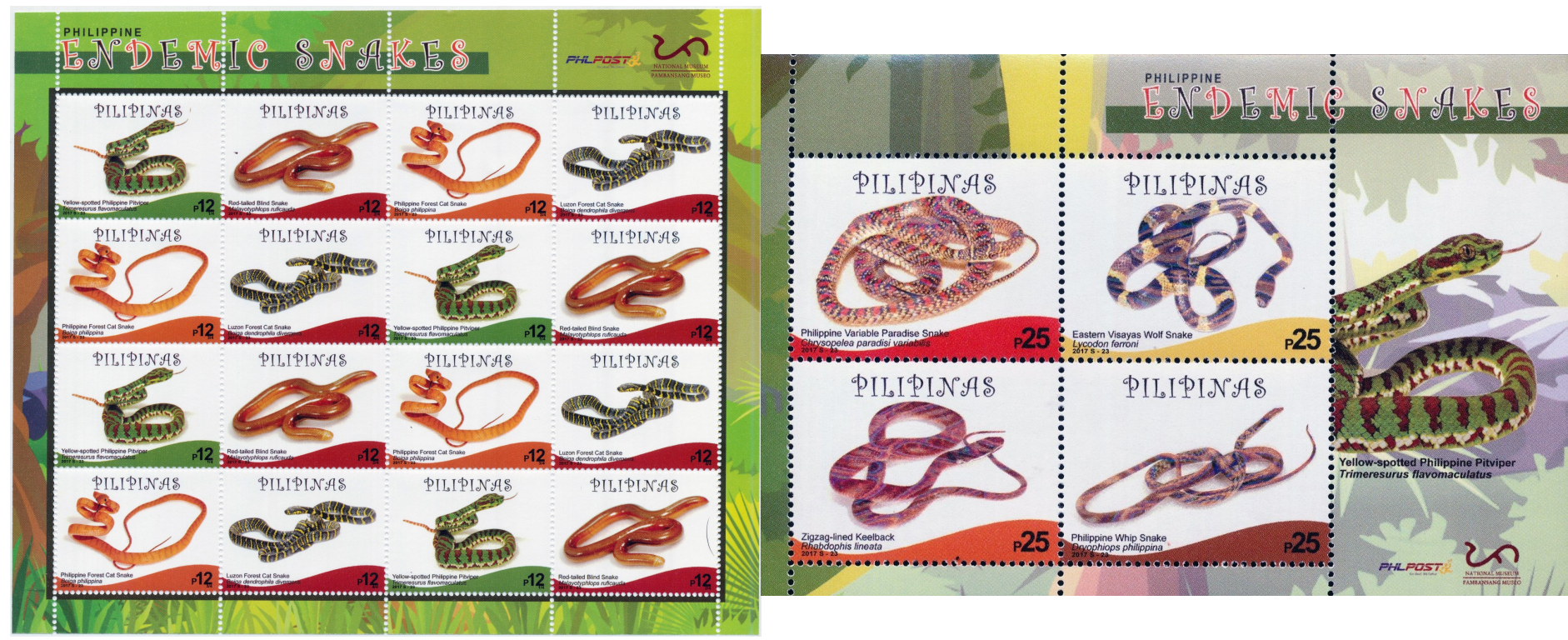

Figure 23. SG awaited (stamps, top; sheetlet, bottom), "Endemic Snakes" (Boiga philippina, Boiga dendrophila divergens, Trimeresurus flavomaculatus, Malayotyphlops ruficaudus, Chrysopelea paradisi variabilis, Lycodon ferroni, Rhabdophis lineatus, and Dryophiops philippina). 
authorities released a series of four stamps (of PHP 12 each) and a sheetlet of four stamps (of PHP 25 each), entitled "Endemic Snakes" (Fig. 23). Snake depicted on the stamps include Boiga philippina, Boiga dendrophila divergens, Trimeresurus flavomaculatus, and Malayotyphlops ruficaudus. As with the lizards, these were printed in se-tenant sheets of four sets each, in different sequences. The sheetlet too depicts four species- Chrysopelea paradisi variabilis, Lycodon ferroni, Rhabdophis lineatus, and Dryophiops philippina. The broad right selvage of the sheetlet shows a Trimeresurus flavomaculatus. In terms of accuracy and aesthetics, these are some of the finest products by the Philippines Post. The sheetlet is printed with a holographic foil, producing a threedimensional effect that shows off the scales of the snakes.

Cancellations or postmarks bearing herpetofaunal motifs (= pictorial cancellations) have been issued for five of these series (Table 2), and depict recognizable species of amphibians and reptiles, all illustrated in the stamps or respective covers for first day of issue.

\section{Conclusions}

The Philippines has done well in its biodiversity issues in philately, and here, we showcase her herpetological stamps. Over the years, the coverage has expanded from solely marine species (such as sea turtles), and reliance on readily available online images of exotic species, to the depiction of rare, endemic and threatened species.

Of the several dozen herpetological species depicted on the stamps of the Philippines, two were described by Alcala and colleagues- an amphibian, Platymantis pygmaeus Alcala et al. (1998) and a reptile, Gekko gigante Brown and Alcala (1978).

The span of nearly four decades that herpetological stamps depicted in the work show a marked change in the type and quality of images, from relatively garish paintings of species, sometimes within a landscape mosaic, as till 1998; photographs and more skilfully executed stamps (such as the Hong Kong 2001 International Stamp Exhibition issues); to the one most recent on the lizards and snakes of the archipelago (both from 2017). Societal values have changed the second herpetological stamp, issued in 1998 to commemorate the Seoul Olympic Games, issued in perforate and imperforate versions, showing a diver holding a juvenile sea turtle. A cardinal rule at present for scuba and other divers in terms of responsible interactions with marine life is non-contact observations. Recreational diving, for instance, has been shown to have the potential to disturb sea turtles (Hayes et al., 2016), and touching or holding turtles and other animals are not only strongly discouraged, these actions may, in fact, be illegal in many parts of the world (PADI, 2018).

Sea turtles, as icons for ecotourism and associated with marine life and even the concern of fisheries, dominate philatelic releases. However, the past decade has seen the issue of smaller, more poorly known members of the country's biodiversity, with the postal authority involving local centers of knowledge to generate accurate images on the stamps.

\section{Acknowledgements}

We are grateful to Arvin Cantor Diesmos for the gift of some of the stamps depicted here, and invitation to write this article; Arvin, Rafe Brown, and Abner Bucol for information; and Aaron Bauer and an anonymous reviewer for their comments. The first author thanks the Institute of Biodiversity and Environmental Conservation, Universiti Malaysia Sarawak for support during manuscript preparation.

\section{LITERATURE CITED}

Alcala, A.C., W.C. Brown \& A.C. Diesmos, 1998. Two new species of the genus Platymantis (Amphibia: Ranidae) from Luzon Island, Philippines. Proceedings of the California Academy of Sciences, 4th Series, 50: 381-388.

Amr Z.S., 2013. Reptiles on postage stamps in Arabian countries in western Asia and North Africa. Russian Journal of Herpetology, 20(1): 27-32.

Balazs G.H., E.D. Gomez \& N.D. Linsley, 1990. Marine turtle postage stamps of the world- promoting conservation. In: Richardson, T.H., Richardson, J.I. \& Donnelly, M. (eds.), Proceedings of the Tenth Annual Workshop on Sea Turtle Biology and Conservation, U.S. Department of Commerce, National Oceanographic and Atmospheric Administration, Miami, pp. 215.

Bearse G.A., W.F. Stanley, M.S. Raasch, U. Stahl, E.O. Bookwater, R.F. Gordon \& M.L. Skaroff, 1977. Lower Vertebrates: Fishes, Amphibia and Reptiles on Stamps of the World, American Topical Association, ATA Handbook 91, Carterville, Illinois, USA. 118 pp.

Borrell, B., 2013. The spy who loved frogs. Nature, 501: 150153. doi:10.1038/501150a

Brown R.M., C.D. Siler, S.J. Richards, A.C. Diesmos \& D.C. Cannatella, 2015. Multilocus phylogeny and a new classification for Southeast Asian and Melanesian forest frogs (family Ceratobatrachidae). Zoological Journal of the Linnean Society, 174: 130-168. https://doi.org/10.1111/ zoj. 12232

Brown, W.C. \& A.C. Alcala, 1978. Philippine lizards of the 
family Gekkonidae. Silliman University Natural Science Monograph Series No. 1, Dumaguete City. v + 146 pp + (1) errata sheet.

Das I., 1994. Herpetological philately. Bulletin of the Chicago Herpetological Society, 29: 200-202.

Das, I., 2014. Herpetological products in philately issued from Malaysia. Russian Journal of Herpetology, 21(1): 13-39.

Das, I., 2015. The unissued philatelic essays of Morocco, featuring herpetofaunal species. Bulletin of the Chicago Herpetological Society, 50(7): 93-95.

Domfil, S., 1992. Fauna Prehistorias y Reptiles. Prehistoric and Reptiles, Domfil Thematic Stamp Catalogues, Sabadell, Spain. 146 pp.

Eichler, V., 2017. Amphibians on postage stamps. American Topical Association Handbook 165. ATA, Carterville, Illinois, USA. $97 \mathrm{pp}$.

Encarnacion, E., 1985. Establishment of the postal system in the Philippines. Philippine Philatelic Newsletter, 7(1): 133.

Gomez E.D. \& G.H. Balazs, 1983. Marine turtle stamps promoting conservation. Chelonian Documentation Center Newsletter, 2(2-4): 15-22.

Hayes, C.T., D.S. Baumbach, D. Juma \& S.G. Dunbar, 2016. Impacts of recreational diving on hawksbill sea turtle (Eretmochelys imbricata) behaviour in a marine protected area. Journal of Sustainable Tourism, 25: 79-95.

IUCN, 2020. The IUCN Red List of Threatened Species. Version 2020-1. Accessed 16 April 2020. http:// www.iucnredlist.org

Nemésio A., D.P. Seixas \& H.L. Vasconcelos, 2013. The public perception of animal diversity: what do postage stamps tell us? Frontiers of Ecology and Environment, 11: 9-10. https://doi.org/10.1890/13.WB.001

PADI, 2018. Project Aware. Specialty Course. Instructor Guide. Version 3. Professional Association of Diving Instructors, Rancho Santa Margarita, CA, USA. 48 pp.

Riemer D., 1993. Chelonian philately: collecting turtles and tortoises on stamps. New York Turtle Tortoise Society News Notes, 4(1): 12-14.

Rings R.W., 2005. The snake as a medical symbol on stamps. Biophilately, 54(34): 155-56.

Thompson C.S., 1959. Reptiles on stamps. Topical Times, 1959: 25-26.

Watermolen D.J., 1995. More herpetological philately. Bulletin of the Chicago Herpetological Society, 30(5): 91-93. 